\title{
Penerapan K-Means Cluster pada Daerah Penggunaan Teknologi di Indonesia
}

\author{
Silvana Fitria Mandang ${ }^{1}$, Betha Nurina Sari ${ }^{2}$ \\ Fakultas Ilmu Komputer, Teknik Informatika \\ Universitas Singaperbangsa Karawang, Indonesia \\ e-mail: ${ }^{1}$ silvana.fmandang17027@ student.unsika.ac.id, ${ }^{2}$ betha.nurina@ staff.unsika.ac.id
}

Diterima: 21 Maret 2021; Direvisi: 19 Mei 2021; Disetujui: 25 Mei 2021

\begin{abstract}
Abstrak
Indonesia saat ini sedang mengalami kondisi yang tidak stabil akibat adanya virus Covid-19. Virus Covid-19 telah menyebar ke seluruh wilayah Indonesia dan menginfeksi ribuan orang. Akibat adanya virus ini hampir semua aspek kehidupan berubah termasuk pendidikan. Pemerintah akhirnya mengeluarkan kebijakan baru dengan mengubah proses belajar dan mengajar tatap muka menjadi daring. Akan tetapi, di Indonesia sendiri perkembangan dan pemanfaatan teknologi komputer dan internet masih belum merata. Umumnya hanya masyarakat perkotaan yang memiliki akses teknologi tinggi dibandingkan dengan pedesaan. Pada penelitian ini akan menerapkan metode clustering k-means pada penggunaan teknologi siswa umur 5-24 tahun selama pembelajaran daring. Dari hasil penelitian menggunakan 34 data provinsi di Indonesia menghasilkan 3 cluster, cluster pertama dengan kategori tinggi sebanyak 7 provinsi, cluster kedua dengan kategori sedang sebanyak 19 provinsi dan cluster ketiga dengan kategori rendah sebanyak 8 provinsi.
\end{abstract}

Kata kunci: Klastering, Data Mining, K-Means, Teknologi

\begin{abstract}
Indonesia is currently experiencing an unstable condition due to the Covid-19 virus. The Covid19 virus has spread throughout Indonesia and infected thousands of people. As a result of this virus, almost all aspects of life have changed, including education. The government finally issued a new policy by changing the face-to-face learning and teaching process to be bold. However, in Indonesia itself, the development and use of computer and internet technology is still not evenly distributed. Only urban communities have access to high technology compared to rural areas. This study will apply the k-means clustering method to the use of technology for students aged 524 years of age during bold learning. From the results of the study using 34 provincial data in Indonesia resulted in 3 clusters, the first cluster with the high category was 7 provinces, the second cluster with the medium category was 19 provinces and the third cluster with the low category was 8 provinces.
\end{abstract}

Keywords: Clustering, Data Mining, K-Means, Technology

\section{PENDAHULUAN}

Indonesia saat ini sedang mengalami kondisi yang tidak stabil akibat adanya virus Covid19. Virus Covid-19 telah menyebar ke seluruh wilayah Indonesia dan menginfeksi ribuan orang. Akibat adanya virus ini hampir semua aspek kehidupan berubah termasuk pendidikan. Pemerintah akhirnya mengeluarkan kebijakan baru dengan mengubah proses belajar dan mengajar tatap muka menjadi daring. Hal ini bertujuan agar meminimalisir penyebaran virus di lingkungan pendidikan. Pembelajaran daring tentunya memerlukan media pendukung seperti teknologi. Teknologi yang 
dibutuhkan untuk mendukung pembelajaran daring adalah komputer dan akses internet. Dampak positif yang bisa diambil dari pembelajaran daring adalah siswa menjadi lebih mandiri dalam mempelajari materi yang bisa diakses melalui internet menggunakan komputer atau gadget. Akan tetapi, di Indonesia sendiri perkembangan dan pemanfaatan teknologi komputer dan internet masih belum merata. Umumnya hanya masyarakat perkotaan yang memiliki akses teknologi tinggi dibandingkan dengan pedesaan. Sehingga pembelajaran daring menjadi kurang efektif bagi beberapa siswa.

Berdasarkan permasalahan maka dibuatlah suatu penelitian untuk menemukan kelompok daerah dengan pemanfaatan teknologi dari rendah, sedang, dan tinggi. Data yang digunakan dalam penelitian ini adalah data-data yang terdapat di website resmi Badan Pusat Statistik tahun 2020 tentang pendidikan pada bulan Agustus sampai November. Metode yang digunakan dalam pengelompokan adalah clustering. Salah satu metode dalam pengelompokkan clustering adalah algoritma k-means. K-means dalam beberapa penelitian dapat digunakan untuk mengelompokkan suatu objek ke dalam cluster berdasarkan nilai rata-rata, seperti pada penelitian yang telah dilakukan oleh Alkhairi yaitu menerapkan algoritma k-means dalam mengelompokkan daerah yang memiliki potensi produksi karet di Indonesia[1]

Untuk memperoleh informasi provinsi mana saja di Indonesia yang mengakses teknologi rendah, sedang, tinggi maka digunaknan teknik pembagiang cluster menggunakan algoritma kmeans. Tahapan penelitian ini berdasarkan tahapan yang terdapat pada data mining dan diimplementasikan menggunakan aplikasi rapidminer. Penelitian ini diharapkan dapat dijadikan bahan evaluasi pemerintah daerah terhadap kebijakan pembelajaran daring.

\section{METODOLOGI PENELITIAN}

\subsection{Data Mining}

Data mining merupakan proses mencari pengetahuan pada basis data menggunakan beberapa metode seperti klasifikasi, asosiasi, klastering dan lain sebagainya. Pemilihan tekink atau algoritma sangat bergantung pada tujuan yang ingin dicapai, sehingga hasil dari pengolahan data menggunakan data mining ini dapat digunakan untuk pengambilan keputusan.

\subsection{Clustering}

Clustering merupakan suatu proses membagi data kedalam beberapa kelompok yang karakternya memiliki kemiripan antara data satu dengan yang lain. Clustering memiliki sifat unsupervised yang artinya metode ini dapat diterapkan tanpa latihan karena tidak memerlukan target keluaran. Clustering memiliki dua jenis teknik dalam proses pengelompokan, yaitu hirarki dan non-hirarki. Umumnya, clustering banyak diimplementasikan kedalam beberapa bidang, seperti bidang ekonomi pada sebuah bisnis untuk menganalisa pasar[2]. Metode clustering juga dapat digunakan untuk pemetaan daerah yang padat, menentukan pola-pola distribusi secara keseluruhan dan menemukan keterkaitan antara atribut-atribut data. Dalam data mining, metode clustering difokuskan untuk menemukan cluster pada basis data berukuran besar secara efektif dan efisien[3].

\subsection{Algoritma K-Means}

Algoritma K-Means merupakan proses yang telah banyak digunakan untuk membagi dan memisahkan data ke dalam beberapa kelompok. Ada dua jenis clustering dalam pengelompokkan data, yaitu hierarchical dan non-hierarchical. Hierarchical merupakan metode pengelompokkan yang memiliki urutan berdasarkan tingkatan, berbeda dengan non-hirarchical, dan algoritma kmeans sendiri merupakan salah satu metode dari non-hierarchical. Clustering K-Means merupakan metode pengelompokan data kedalam beberapa klaster. Pengelompokkan data tersebut berdasarkan karakteristik dari data yang dimiliki, sehingga data yang memiliki 
karakteristi mirip akan dikumpulkan dalam satu klaster dan data yang memiliki karakteristik berbeda akan dikumpulkan ke klaster yang lain. Untuk mengelompokkan data menggunakan algoritma clustering k-means, langkah-langkah yang dilakukan sebagai berikut [4]:

1. Langkah pertama adalah penentuan jumlah cluster. Jumlah cluster yang akan dibentuk sebanyak 3.

2. Menentukan centroid awal. Penentuan centroid awal dapat dilakukan dengan memilih data secara acak.

3. Menghitung jarak data ke centroid menggunakan rumus jarak Euclidean yang dirumuskan sebagaimana dalam persamaan 1 berikut :

$$
D_{(a, b)}=\sqrt{\left(x_{1 a}-y_{1} b\right)^{2}+\left(x_{2 a}-y_{2} b\right)^{2}+\cdots \cdot+\left(x_{c a}-y_{c b}\right)^{2}}
$$

Keterangan:

$$
\begin{aligned}
\mathrm{D}(\mathrm{a}, \mathrm{b}) & =\text { Jarak data } \mathrm{a} \text { ke centroid } \mathrm{b} \\
X_{1 \mathrm{a}} & =\text { Data ke } 1 \text { pada atribut data ke } \mathrm{a} \\
X_{2 \mathrm{a}} & =\text { Data ke } 2 \text { pada atribut data ke } \mathrm{a} \\
\mathrm{Y}_{1} \mathrm{~b} & =\text { Data centroid ke } 1 \text { pada atribut } \mathrm{b} \\
\mathrm{Y}_{2} \mathrm{~b} & =\text { Data centroid ke } 2 \text { pada atribut } \mathrm{b} \\
X_{\mathrm{ca}} & =\text { Data ke } \mathrm{c} \text { pada atribut data ke } \mathrm{a} \\
\mathrm{Y}_{\mathrm{cb}} & =\text { Data centroid ke } \mathrm{c} \text { pada atribut } \mathrm{b}
\end{aligned}
$$

4. Kelompokkan data yang telah dihitung menggunakan rumus euclidean tersebut berdasarkan jarak paling dengat dengan nilai centroid.

5. Hitung kembali keanggotaan cluster dengan nilai centroid baru. Nilai centroid baru dapat diperoleh dari rata-rata cluster.

6. Lakukan perulangan pada langkah tiga sampai lima, sampai data tidak berpindah ke cluster lain.

\subsection{Davies-Bouldin Index (DBI)}

Davies-Bouldin Index merupakan salah satu metode untuk mengukur evaluasi jumlah cluster pada suatu metode pengelompokan data[5]. Suatu cluster akan dianggap memiliki skema clustering yang baik apabila memiliki nilai DBI paling rendah [6].

\section{HASIL DAN PEMBAHASAN}

Pada penelitian ini data yang digunakan didapat dari situs Badan Pusat Statistik. Data yang dipilih adalah data persentase siswa umur 5-24 tahun yang menggunakan telepon seluler, menggunakan komputer dan menggunakan internet selama bulan Agustus sampai November 2020 menurut Provinsi. Kemudian data di preprocessing sesuai dengan kebutuhan dengan memanfaatkan software microsoft excel. Data tersebut akan dikelompokkan berdasarkan cluster 1 dengan tertinggi, cluster 2 dengan sedang, cluster 3 dengan rendah. Data yang akan digunakan menurut provinsi ditunjukkan pada tabel 1:

Tabel 1. Persentase siswa umur 5-24 tahun yang menggunakan teknologi

\begin{tabular}{l|cccc}
\hline \multirow{2}{*}{ Provinsi } & \multicolumn{3}{|c}{ Persentase Siswa yang menggunakan teknologi } \\
\cline { 2 - 4 } & $\begin{array}{c}\text { Telepon } \\
\text { Seluler }\end{array}$ & $\begin{array}{c}\text { Menggunakan } \\
\text { Komputer }\end{array}$ & $\begin{array}{c}\text { Menggunakan } \\
\text { Internet }\end{array}$ \\
\hline Bengkulu & 75,44 & 22,15 & 54,49 \\
Sulawesi Barat & 69,58 & 16,08 & 41,82 \\
Jawa Tengah & 81,62 & 27,56 & 69,33
\end{tabular}




\begin{tabular}{|c|c|c|c|}
\hline Aceh & 67,53 & 14,08 & 40,48 \\
\hline Sulawesi Tengah & 74,35 & 17,92 & 50,28 \\
\hline Bali & 85,5 & 30,68 & 71,49 \\
\hline Jambi & 72,8 & 19,68 & 53,92 \\
\hline Lampung & 77,94 & 18,14 & 56,15 \\
\hline Gorontalo & 83,15 & 23,95 & 56,77 \\
\hline Kep. Riau & 72,66 & 24,83 & 52,58 \\
\hline Jawa Barat & 75,78 & 24,36 & 64,39 \\
\hline Tenggara & 69,48 & 14,84 & 31,39 \\
\hline \multicolumn{4}{|l|}{ Timur } \\
\hline Riau & 78,68 & 21,18 & 53,86 \\
\hline Sumatera Selatan & 76,14 & 18,14 & 52,97 \\
\hline Sumatera Utara & 77,15 & 22,23 & 51,54 \\
\hline DKI Jakarta & 80,81 & 34,37 & 69,93 \\
\hline Sumatera Barat & 77,74 & 26,04 & 51,21 \\
\hline Sulawesi Tenggara & 77,56 & 18,78 & 50,32 \\
\hline Kalimantan Timur & 83,18 & 23,34 & 68,51 \\
\hline Sulawesi Utara & 74,6 & 18,96 & 57,24 \\
\hline Jawa Timur & 82,05 & 31,01 & 67,53 \\
\hline Sulawesi Selatan & 82,43 & 22,99 & 57,99 \\
\hline DI Yogyakarta & 90,55 & 45,7 & 83,21 \\
\hline Papua Barat & 66,25 & 13,28 & 47,33 \\
\hline Kalimantan Utara & 84,7 & 21,41 & 59,47 \\
\hline Maluku Utara & 58,98 & 12,54 & 35,72 \\
\hline Tenggara & 81,96 & 20,26 & 53,58 \\
\hline \multicolumn{4}{|l|}{ Barat } \\
\hline Kalimantan Selatan & 83,64 & 37,3 & 65,21 \\
\hline Maluku & 66,45 & 17,88 & 41,67 \\
\hline Bangka & 79,81 & 20,92 & 58,92 \\
\hline \multicolumn{4}{|l|}{ Belitung } \\
\hline Kalimantan Barat & 67,8 & 14,58 & 49,63 \\
\hline Kalimantan Tengah & 74,78 & 18,06 & 54,26 \\
\hline Papua & 41,24 & 9,7 & 26,46 \\
\hline
\end{tabular}

1. Penerapan Algoritma K-Means

Langkah yang perlu dilakukan untuk mengelompokkan data ke beberapa cluster menggunakan algoritma k-means:

a. Tentukan jumlah cluster. Pada penelitian ini data di atas dikelompokkan menjadi 3 cluster.

b. Selanjutnya tentukan centroid awal. Untuk menentukan centroid awal, diambil dari data di atas secara acak dan centroid awal yang dipilih adalah pada tabel 2:

Tabel 2. Centroid awal

\begin{tabular}{llll}
\hline $\mathrm{C} 1$ & 75,78 & 24,36 & 64,38 \\
\hline $\mathrm{C} 2$ & 74,78 & 18,06 & 54,26 \\
\hline $\mathrm{C} 3$ & 74,35 & 17,92 & 50,28 \\
\hline
\end{tabular}

c. Hitung jarak data pada masing-masing nilai centroid menggunakan rumus euclidean distance sebagai berikut:

$C 1=\sqrt{(67,53-75,78)^{2}+(14,08-24,36)^{2}+(40,48-64,39)^{2}}$ 
$\mathrm{C} 1=27,30254567$

$\mathrm{C} 2=\sqrt{(67,53-74,78)^{2}+(14,08-18,06)^{2}+(40,48-54,26)^{2}}$

$\mathrm{C} 2=16,07144362$

$\mathrm{C} 3=\sqrt{(67,53-74,35)^{2}+(14,08-17,92)^{2}+(40,48-50,28)^{2}}$

$\mathrm{C} 3=12,54184994$

Perhitungan jarak pada nilai centroid dilakukan seterusnya sampai data terakhir yaitu data ke 34. Hasil dari perhitungan data terhadap nilai centroid tersebut akan menjadi anggota dari setiap cluster yang memiliki jarak terdekat dari pusat clusternya. Perhitungan terhadap nilai centroid dilakukan sampai proses iterasi cluster tidak berubah lagi. Pada penelitian ini proses berhenti pada iterasi keempat. Sehingga didapatkan nilai ditunjukkan pada tabel 3:

Tabel 3. Pengelompokan data berdasarkan cluster

\begin{tabular}{|c|c|c|c|}
\hline $\mathrm{C1}$ & $\mathrm{C} 2$ & $\mathrm{C3}$ & Cluster \\
\hline 37,65757562 & 18,35245409 & 1,342203275 & 3 \\
\hline 21,52402499 & 3,269927989 & 16,60009618 & 2 \\
\hline 20,26784341 & 6,160317123 & 18,79132066 & 2 \\
\hline 19,72802135 & 1,626607221 & 18,68812911 & 2 \\
\hline 22,4821335 & 4,616370766 & 15,03472331 & 2 \\
\hline 22,80838172 & 3,311145882 & 15,57485095 & 2 \\
\hline 19,68406276 & 2,198369635 & 17,63986679 & 2 \\
\hline 20,03190896 & 3,259387527 & 19,1186723 & 2 \\
\hline 15,78961372 & 5,1132036 & 22,99642153 & 2 \\
\hline 21,32690734 & 6,346179406 & 16,4056904 & 2 \\
\hline 3,314875799 & 20,81007307 & 37,62445215 & 1 \\
\hline 11,69138044 & 10,5791676 & 26,77774704 & 2 \\
\hline 4,460199162 & 16,84652852 & 34,41421774 & 1 \\
\hline 20,6874878 & 40,22606273 & 57,4568877 & 1 \\
\hline 2,67815264 & 17,19783722 & 34,63387308 & 1 \\
\hline 23,75682274 & 9,220916063 & 15,44863484 & 2 \\
\hline 3,226341049 & 21,28821879 & 39,14260671 & 1 \\
\hline 20,04457599 & 4,865250153 & 20,52692128 & 2 \\
\hline 44,20449894 & 25,11518909 & 10,18032094 & 3 \\
\hline 30,60771678 & 12,33251633 & 8,570297797 & 3 \\
\hline 22,37144109 & 3,727147307 & 15,81310421 & 2 \\
\hline 7,306731592 & 20,63530564 & 37,12488098 & 1 \\
\hline 8,576682142 & 15,41490522 & 33,13420534 & 1 \\
\hline 14,86090093 & 8,989346197 & 26,61309394 & 2 \\
\hline 19,8720363 & 4,237548236 & 18,46401759 & 2 \\
\hline 25,53896536 & 5,900205679 & 12,39983056 & 2 \\
\hline 14,85578512 & 6,614048159 & 24,54869869 & 2 \\
\hline 24,14579107 & 4,691742006 & 14,86105744 & 2 \\
\hline 15,33769707 & 7,054311664 & 24,5582664 & 2 \\
\hline 34,86101514 & 15,56708679 & 3,346625069 & 3 \\
\hline 35,54660605 & 17,02417337 & 3,171617041 & 3 \\
\hline 45,97829136 & 27,48001388 & 9,599676534 & 3 \\
\hline 33,63355024 & 15,14827644 & 6,363446467 & 3 \\
\hline 64,14183367 & 46,97017201 & 29,72350283 & 3 \\
\hline
\end{tabular}

2. Implementasi pada Rapidminer 
Tahap ini merupakan tahap implementasi dari Algoritma K-Means menggunakan aplikasi RapidMiner. Berdasarkan Gambar 1 pemodelan algoritma clustering k-means diperoleh hasil yang serupa dengan perhitungan manual. Dari ketiga cluster yang diterapkan pada model menghasilkan cluster 0 sejumlah 7 items, cluster 1 sejumlah 19 items, dan cluster 2 sebanyak 8 items.

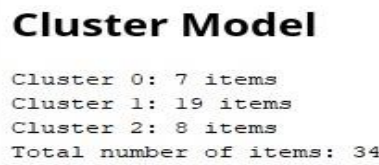

Gambar 1. Hasil cluster dalam rapidminer

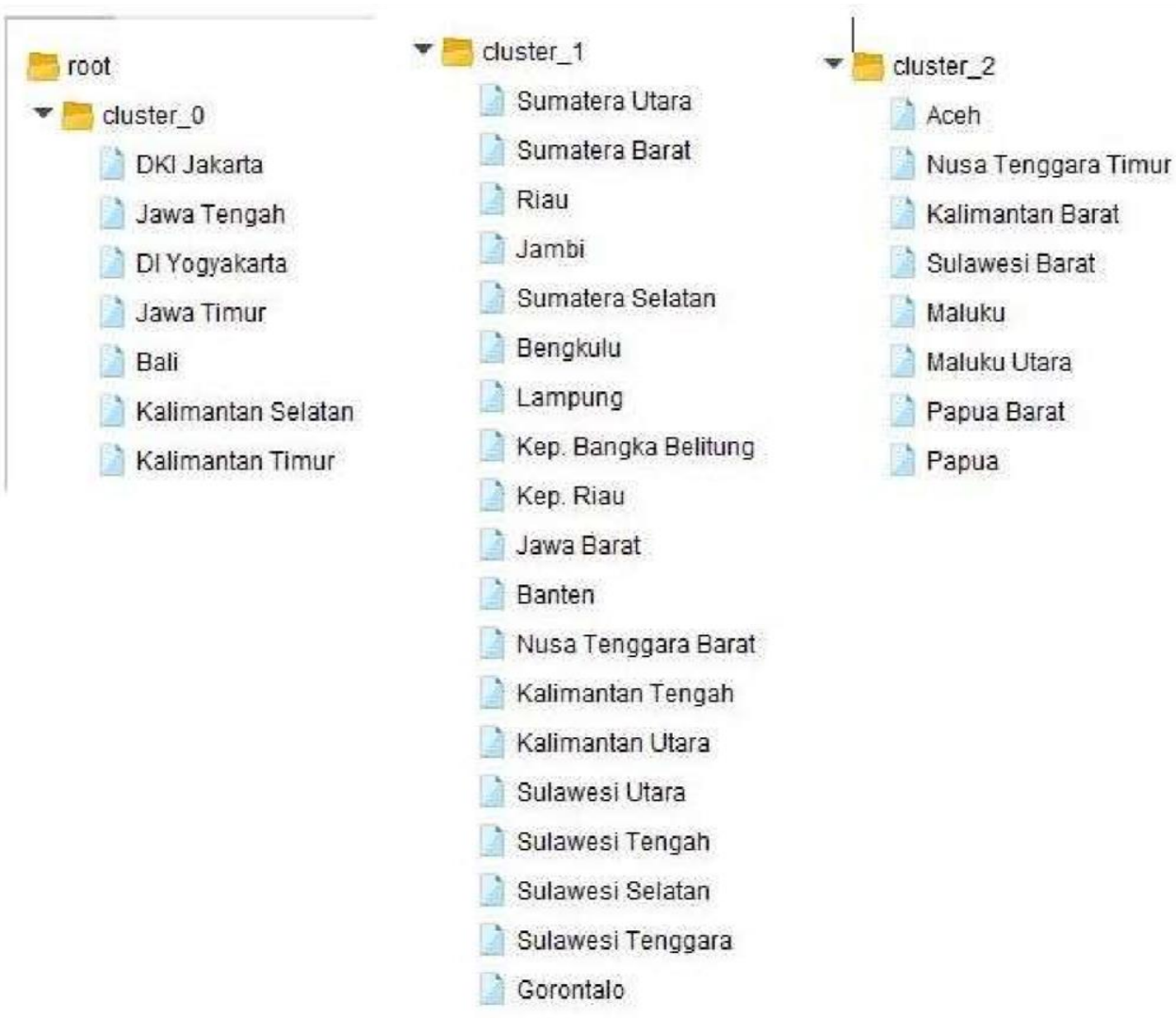

Gambar 2. Hasil cluster dalam rapidminer

Dapat disimpulkan bahwa cluster terhadap persebaran penggunaan teknologi pada siswa usia 524 tahun di Indonesia:

a. Cluster 1 (Tinggi) adalah Bali, Jawa Tengah, Jawa Timur, DI Yogyakarta, Kalimantan Selatan, Kalimantan Timur, DKI Jakarta.

b. Cluster 2 (Sedang) adalah Bengkulu, Riau, Sulawesi Utara, Kalimantan Tengah, Sumatera Utara, Jambi, Jawa Barat, Sumatra Barat, Lampung, Kep. Bangka Belitung, Sulawesi Selatan, Kep. Riau, Banten, Gorontalo, Kalinantan Utara, Sulawesi Tengah, Sulawesi Tenggara, Sumatera Selatan, Nusa Tenggara Barat.

c. Cluster 3 (Rendah) adalah Papua Barat, Maluku, Aceh, Sulawesi Barat, Papua, Kalimantan Barat, Maluku Utara, Nusa Tenggara Timur. 
Penentuan cluster didasarkan pada hasil perhitungan dimana hasil yang paling kecil atau mendekati dengan nilai centroid merupakan cluster tersebut. Hasil akhir yang didapatkan dari centroid akhir ditunjukkan oleh tabel 4:

Tabel 4. Hasil centroid akhir

\begin{tabular}{llll}
\hline Attribute & Cluster 1 & Cluster 2 & Cluster 3 \\
\hline Telepon Seluler & 83,907 & 77,147 & 63,414 \\
Menggunakan Komputer & 32,851 & 21,048 & 14,122 \\
Menggunakan Internet & 70,744 & 55,030 & 39,312 \\
\hline
\end{tabular}

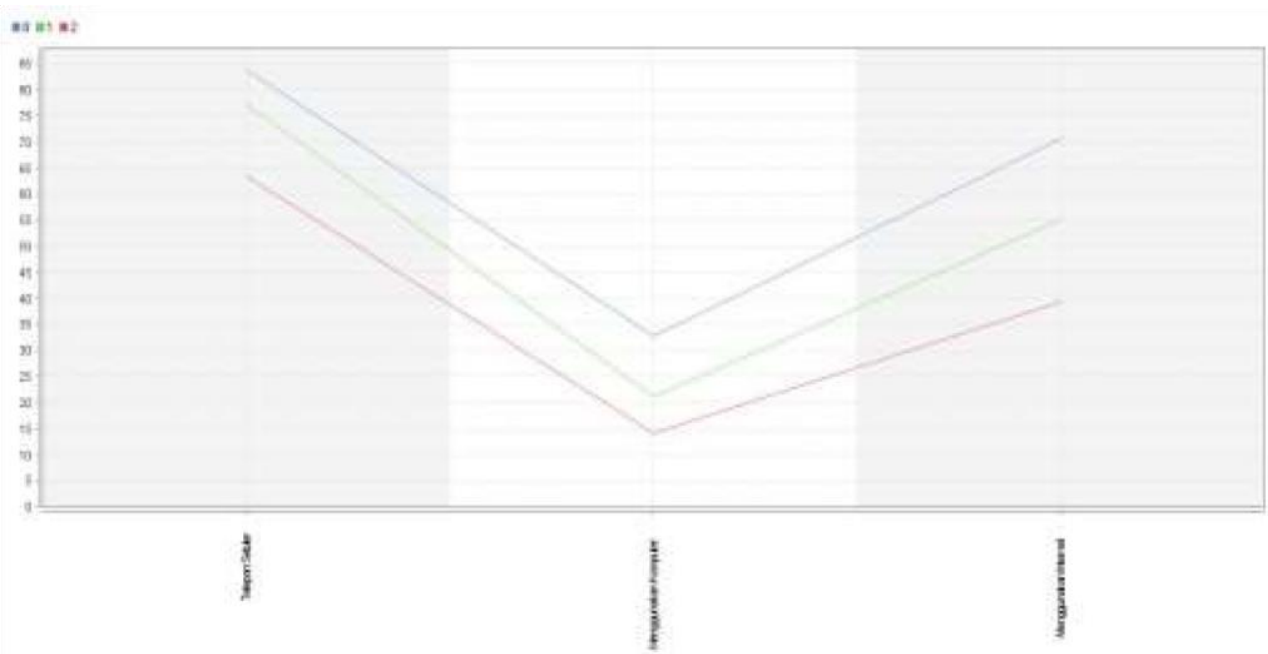

Gambar 3. Grafik hasil clustering k-means

3. Evaluasi

Evaluasi yang digunakan adalah DBI atau Davies-Bouldin Index. Metode evaluasi DBI umum digunakan dalam mengukur kinerja dari pengelompokkan cluster. Pada rapidminer untuk melakukan hasil uji performance operator yang digunakan adalah cluster distance performance. Operator tersebut juga berfungsi untuk mengukur seberapa baik kinerja dari centroid yang dihasilkan. Hasil uji menggunakan rapidminer nilai DBI yang didapatkan sebesar 0,222. Hal ini dikatakan cukup optimal karena apabila nilai DBI mendekati sama dengan nol maka kinerja dari sebuah cluster adalah optimal. Nilai DBI yang dihasilkan pada rapidminer ditunjukkan pada gambar 4:

\section{PerformanceVector}

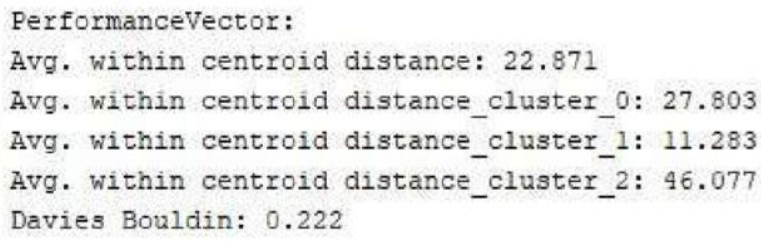

Gambar 4. Hasil uji performance 


\section{KESIMPULAN}

Hasil pada penelitian ini didapat 3 cluster dengan kelompok yang terbentuk berdasarkan nilai tinggi, sedang, rendah dari persentase siswa 5-24 tahun yang menggunakan teknologi selama pembelajaran daring bulan agustus sampai dengan November 2020. Hasil masing-masing cluster didapat cluster 1 sejumlah 7 provinsi, cluster 2 sejumlah 19 provinsi, cluster 3 sejumlah 8 provinsi. Berdasarkan evaluasi kinerja metode menggunakan Davies-Bouldin Index (DBI) didapatkan nilai cukup optimal yaitu 0,222.

\section{DAFTAR PUSTAKA}

[1] P. Alkhairi and A. P. Windarto, "Penerapan K-Means Cluster pada Daerah Potensi Pertanian Karet Produktif di Sumatera Utara," Semin. Nas. Teknol. Komput. Sains, pp. 762-767, 2019.

[2] A. Aditya, I. Jovian, and B. N. Sari, "Implementasi K-Means Clustering Ujian Nasional Sekolah Menengah Pertama di Indonesia Tahun 2018/2019," J. Media Inform. Budidarma, vol. 4, no. 1, p. 51, 2020, doi: 10.30865/mib.v4i1.1784.

[3] Z. Aras and Sarjono, "Analisis Data Mining Untuk Menentukan Kelompok Prioritas Penerima Bantuan Bedah Rumah Menggunakan Metode Clustering K-Means( Studi Kasus : Kantor Kecamatan Bahar Utara),” J. Manaj. Sist. Inf., vol. 1, no. 2, pp. 159-170, 2016.

[4] A. T. R. Saragih, A. S. Sembiring, and M. Sayuthi, "Penerapan Metode Clustering KMeans untuk Proses Seleksi Calon Peserta Lomba MTQ," Pelita Inform., vol. 17, no. April, pp. 117-122, 2018, [Online]. Available: https://ejurnal.stmikbudidarma.ac.id/index.php/pelita/article/download/776/704.

[5] A. F. Muhammad, "Klasterisasi Proses Seleksi Pemain Menggunakan Algoritma K-Means (Study Kasus : Tim Hockey Kabupaten Kendal)," Jur. Tek. Inform. FIK UDINUS, pp. 1$5,2015$.

[6] I. Kamila, U. Khairunnisa, and M. Mustakim, "Perbandingan Algoritma K-Means dan KMedoids untuk Pengelompokan Data Transaksi Bongkar Muat di Provinsi Riau," J. Ilm. Rekayasa dan Manaj. Sist. Inf., vol. 5, no. 1, p. 119, 2019, doi: 10.24014/rmsi.v5i1.7381. 